ECONOMICS

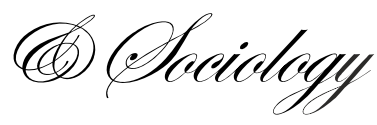

\author{
Mimo Draskovic, \\ University of Montenegro, \\ Kotor, Montenegro, \\ E-mail: rookie@t-com.me
}

Received: September, 2015

1st Revision: October, 2015

Accepted: January, 2016

DOI: $10.14254 / 2071-$

789X.2016/9-1/14
Draskovic, M. (2016), Roots and Paradoxes of Neoliberal Apologetics, Economics and Sociology, Vol. 9, No 1, pp. 209-219. DOI: 10.14254/2071-789X.2016/9-1/14

\section{ROOTS AND PARADOXES OF NEOLIBERAL APOLOGETICS}

\begin{abstract}
In both economic theory and practice, there is a dichotomy between individual behavior and institutional structure. It causes the problem of finding a non-conflict „co-evolution“ of individuals and institutions. Systemic motivation, the ways of business regulation and economic development directly depend on the degree of compliance between individuals and institutions. In this article we will try to explain the difference between the theoretical level, where methodological individualism and methodological holism irreconcilably distance themselves, and the practical level, where synthesis (institutional pluralism) between polarized institutional monisms becomes possible. Socioeconomic development essentially requires institutional pluralism, which per se excludes all forms of institutional monism and the existence of resulting alternative institutions. We can conclude that neoliberal apologetics can be called a specific form of neoliberal (elitist) dirigisme, because it indirectly justifies and protects quasi-neoliberal interests of the so-called „new elite“.
\end{abstract}

JEL Classification: O17, P37 Keywords: neoliberal apologetics, methodological individualism, methodological holism, institutional pluralism.

\title{
Introduction
}

The history of economic thought has developed not only in theory (as a scientific generalization of processes and phenomena in economic reality, based on real facts, events and processes) but also in its doctrinal form (as a start from the predicted set of principles and conditions). In economic theory, there are two principally different ways of explaining the processes and phenomena of economic reality: methodological individualism and methodological holism. L. Udehn (2002) believes there is a discrepancy in literature regarding the contents of methodological individualism.

V. Draskovic \& M. Draskovic (2013, p. 273) and Lakic \& Draskovic (2015a,b) start from the hypothesis that methodological individualism ,is the dominant monistic-ideological platform of contemporary economic theory, from which individual economic policies selectively derive neoliberal basis". According to them, it is a routine and one-way (monistic) course, which is institutionally polarized with another course, which can be labeled as a monistic dirigisme. Polarized discussions of the representatives of the aforementioned theoretical courses have marked the full development of economic thought. There is a different understanding of the role of state regulation and market regulation in the economy, 
their interrelation and appropriate form of ownership, as well as indirect (and direct, and even apologetic) aspirations for decisive influence on official economic policy.

Generalizing different definitions, it can be concluded that methodological individualism is the principle through which society is viewed as a collection of individuals, thus studying social phenomena, processes and social groups in their dynamics is reduced to studying individual behavior. As applied in economic theory, it is used to prioritize individual economic behavior, even in studying economic institutions as regulators, coordinators and limiters of economic behavior. Methodological individualism does not deny the existence of complex social phenomena such as institutions, norms and network of social relations, but considers that their explanation must be based on individual properties solely.

Methodological individualism is essentially a reductionistic scientific platform, with predominantly monistic character. Because social and economic phenomena are given exclusively individual significance, rather than seen in a synergic and pluralistic context of mutual complementary acting of a number of influence factors, many authors believe that external factors are important in explaining human actions and behavior. Individuals act in their environment and respond to it through the perception of their own limitations.

Thus, for example, G. Hodgson (2007) has criticized the attitudes of respectable economic theories, which have completely reduced the economic regulation at individuals. Methodological individualism is often placed in a valuable level with methodological holism, which prefers super-individual social categories (collective systems) and views society as a whole system, different from the sum of individuals it is made of. In economic theory, there are constant debates between the representatives of methodological individualism and methodological holism. F. Toboso (2008) has widely elaborated that phenomena, associating institutional economic theories with methodological individualism, and traditional institutionalism (the so-called Heterodox economy) with methodological holism. Similar views have D. Dequech (2007), L. Davis (2006) and T. Lawson (2006).

\section{Literature review}

There were also attempts to find a third way (middle way) in the economic analysis, but a greater synthesis has not been achieved. In this regard, J. Agassi (1960, p. 247) has formulated the principle of ,institutional individualism“, which supposes the activity of institutions as the cause of people's behavior. L. Udehn (2002, p. 490) points out that these principles have been supported by R. Coase, J. Buchanan, D. North and O. Williamson. F. Toboso $(2001,2008)$ has considered it as a non-systemic and synthetic way of nonreductionist explanation of economic reality. Following the example of institutional individualism, appeared other terminological surrogates, such as „methodological institutionalism“ (Frolov, 2007), „methodological relativism“ and „methodological subjectivism“ (Rubinstein, 2013) and „methodological structuralism“ (Hodgson, 2007).

Despite various attempts, there has not been synthesis of methodological individualism and methodological holism in the economic literature. But there is an increasing advocacy of institutional pluralism as a synthetic form of institutional monism (state regulation and market regulation), in a direct and indirect way. It can be viewed as a „third way“ and synergism of institutional monisms in the economic development. However, it can never be brought in connection with the synthesis of the above discussed principles (methodological individualism and methodological holism). Their only relation exists in the influence of methodological individualism at monism of the market regulation (Figure 1), and this connection was used to create neoliberal theory and practice. 

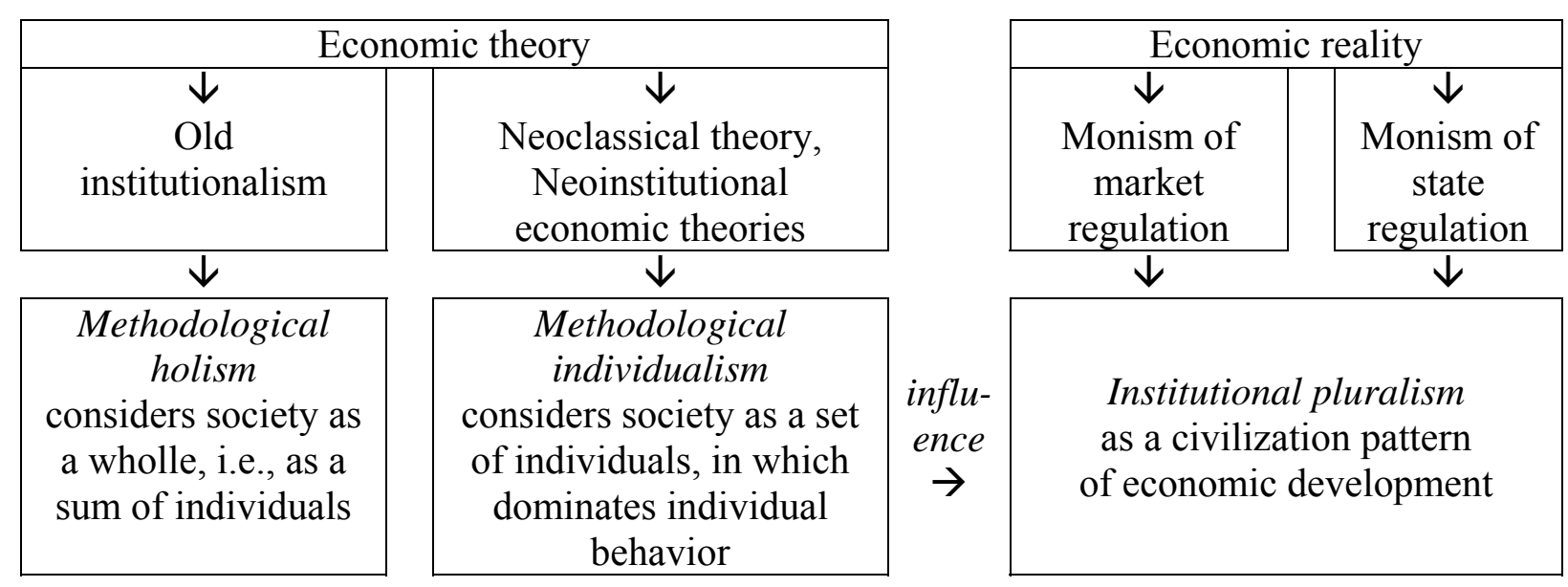

Figure 1. The difference between institutional pluralism and institutional individualism Source: Author's creation.

Representatives of economy convention, regardless of selective respect for methodological individualism, also impose the idea of institutional pluralism, because through the prism of the so-called ,interpretative rationality" they come to the conclusion that free market and state intervention are not the only universal forms of coordination. This convincingly shows the economic reality of developed countries, where components of most institutional arrangements and overall institutional order are individually and collectively inseparable. That should be an exemplary model of civilization.

As a result of all that, the neoliberal insistence of Lj. Madzar (2015) on confronting the monistic institutional alternatives - liberalism vs. communitarianism - is incomprehensible. Thereby, he believes that communitarianism is a generic term for all variants of totalitarian organization. He is constantly focused on the collectivist deformation. But he did not mention quasi-neoliberal individualistic perversion. In addition, the Madzar does not see the only real, exemplary civilizational confrontation alternative to the mentioned monistic institutional alternatives, which is called institutional pluralism.

In the following presentation, we assume that institutional monism of state regulation (dirigisme) is superseded long ago, even among the ideological heirs of the socialist system. However, in the economic literature of many countries which have been going through the process of transition, especially in the post-socialist countries, the institutional monism of the market (neoliberal) type is actual. It is directly paradoxical, primarily because the corresponding theoretical model is not applied in practice, but it is substituted by the quasineoliberal behavior. Due to the exclusive apologetic interest, non-existent state dirigisme, as alleged anti-liberalism, is unduly and paradoxically opposed to neoliberalism.

Therefore, we will analyze in more detail the contemporary apologetics of neoliberal institutional monism as an example of a long-term economic discussions being conducted in Serbia. It is worth of noting that countries in the region have a similar situation, consistently implementing neoliberal economic policies, which is just a cover for various negative manifestations of quasi-neoliberalism in economic reality.

It is necessary to point out another paradox, which might be called the D. North's paradox, and is contained in his (1997, p. 25) famous statement: „The economy appears as a theory of choice... However, this discipline does not study the context in which the choice is being made". The above mentioned paradox emphasizes the role and significance of institutions. It functionally fits into the explanation of a large gap between the theoretical neoliberal lamenting and practical quasi-neoliberal behavior. In an individualist neoliberal 
world there is not enough space for institutions of state regulation, and without them the normal functioning of institutions of market regulation is impossible.

\section{Modern apologetics of neoliberal institutional monism}

In Serbia, turbulent and harsh polemics between the neoliberals and ,,anti-liberals“ have been existing for a long time (which liberals have unduly named the alleged supporters of dirigisme and protectionism - university professors of economic science). This discussion has brought together a large number of economists, whose works were published in the journal „Economic Ideas and Practice,“ No. 16-17/2015. Some articles for the scientific conference, titled: Our scientific disputes: The liberal and communitarian option in institution building and economic policy (Belgrade, March 20, 2015), have been printed in huge numbers of pages. In the terms of supporters of neoliberalism, we estimate that this discussion was extremely dysfunctional and apologetic, regarding four main reasons:

- Classification on the ,liberals“" and ,anti-liberals“ is incosnistent (it should be on the quasi-liberals and neo-liberals),

- Criticism is directed wrongly and virtually (on the alleged ,anti-liberals“, rather than the quasi-neoliberals),

- There is no difference between liberalism and neo-liberalism, and

- Neoliberal apologetics does not reach to the core - objective existence and dominance of alternative institutions, on the contrary, it covers it up and ignores it.

Despite of the ambitiously expressed pretension of a neoliberal economist Ljubomir Madzar (2015, p. 2) that this is about the alleged ,doctrinal and paradigmatic conflict" and its „,continuing significance“, his „,dealing with them“ (with Serbian anti-liberals - M.D.'s note), is, however, only limited, special and incorrectly selected case, with ambitions to become universal, primarily due to the substantial conceptual errors and classic replacement thesis. Therefore, we will try to show the pointlessness of this discussion between Serbian neoliberal economists. In doing so, the subject of our criticism will be focused primarily on their substantial devotion to the institutional monism (market-type), according to the above alleged classification of economists on liberals and anti-liberals.

We believe that the above classification is illusory and directed only towards the apologetic glorification of neoliberalism. Because a neoliberal theoretical model does not work in practice, that is only its rhetorical facade and practical incarnation, which is vulgarized and transformed into a specific and rigid form of institutional monism, which we call quasi-neoliberalism. Clearly, the quasi-totalitarian neoliberalism is specific form of a social engineering. This paper descriptively and analytically tries to prove that its nonrecognition and non-dissimilarity of neoliberalism has apologetic background - justifying the existing unjust order.

Analyzing the numerous texts of dubbed ,anti-liberals“, we have not noticed that they dirigisme oriented, as they are attributed. On the contrary, they have never and nowhere denied the ,affirmation of the market“, which is pretty lacking in the practice of Southeast Europe (dominated by monopoly and other pseudo-market structures), not to mention nonexistence of the integrated market. They have also not denied the need of ,radically changed role of the state and the rule of law", mentioned by Madzar (Ibid). But they have mentioned the need for stronger and more efficient state regulation in combination with market regulation, (i.e. institutional pluralism).

Wherever you mention the term 'state regulation', except in the minimalist versions, it causes negative emotions among the self-styled neoliberals, who pretentiously continue to orchestrate the apologetics, based on a dogma and futile rhetoric. Therefore, it is necessary to 
answer the core question: What is the essence of their dogma and apologetics? Obviously, a simple answer regarding the dogma is imposed by three facts:

- neoliberals insisting on the conflict of alleged ,institutional alternative“ (i.e. on the clash of institutional monisms),

- inventing the apparently risen dirigisme, and

- avoiding the affirmation of institutional pluralism as a proven, non-alternative, and civilized condition for socio-economic development. In terms of neoliberal apologetics the answer is simple: It is contained in avoiding the evident quasineoliberalism in practice, which manifested as deformed and devastating development form of (theoretical) model of neoliberalism.

The main critic of the so-called ,,anti-liberalism“ (at least according to the extent of written pages - 311), Madzar (Ibid) starts from rhetorical support of neoliberalism, calling it „an appealing consistency“ and „influential hotbed of liberal ideas“. To his theoretical opponents he imputes the ignorance and dirigisme. Thereby, he falls into a trap of theoretical inconsistency and inaccuracy, because for the comparison of allegedly conflicting economic institutions (Ibid., p. 7) he uses the terms "state“ and „market" rather than adequate terms „market regulation“" and „state regulation“.

Madzar (Ibid., p. 2) notices a „voluntary operation of the state“, but does not specify who and why operates it (presumably nomenclature of authority for personal interests M.D.'s note). In other words, he does not notice the quasi-neoliberal misuse of state regulation. On the contrary, he neutrally blames the „opposite assessments of social rationality of non-market entrepreneurial, economic and development operation" (between liberals and anti-liberals - M.D.'s note), rather than perceiving the privileged (non-market) enrichment and ,protectionism of nomenclature authority towards its own people“ (term of Draskovic, 2014, pp. 14, 32, 77).

Accordingly, Madzar (Ibid.) declares the alleged anti-liberals the „numerous, surprisingly powerful and socially influential army of professional activists“. It is hard to imagine specified depth according to which university professors have become powerful and influential! It proves the consistency of his apologetic blindness, because he does not notice really powerful people from the ranks of the quasi-neoliberals, under the paradoxical banner of „obviousness“. Although really powerful people persistently retain and maintain official state neoliberal macroeconomic politics, he does not worry about them. Rather, he writes (p. 26) that ,economists of liberal orientation are less willing to attribute the unfavorable tendencies to the personalities and teams who make decisions."

Instead of specific personalities and groups, Madzar generally and apologetically declares the „system error“" and „conspiracy theory“ (Ibid, pp. 31-32). This practically means that he ignores the existence of official neoliberal economic policy and non-market enriched decision-makers (government nomenclature, tycoons, nouveau-riche entrepreneurs and other privileged subjects called the „new elite“). Even the rest of the neoliberals, participating in this discussion (Begovic, Prokopijevic, Mijatovic et al.) do not see the difference between modeled neoliberalism and practical quasi-neoliberalism. Besides, they believe that neoliberalism is not different from classical liberalism, which are identified according to them.

Different levels of opportunistic motivation and privilege (in theory and practice) have been created in relation to the level and the size of interest (large, medium and small). Neoliberals are at the lowest level of interest and privilege, which corresponds to their opportunistic function (satellite, apologetic and rhetorical) - Table 1. 
Table 1. Hierarchy and characteristics of neoliberal and quasi-neoliberal levels

\begin{tabular}{cccc}
\hline $\begin{array}{c}\text { Level of } \\
\text { interest and } \\
\text { privilege }\end{array}$ & $\begin{array}{c}\text { Area of } \\
\text { action }\end{array}$ & Name & Opportunistic function \\
\hline highest & practice & nomenclature authorities & providing anti-institutional conditions \\
\hline middle & practice & $\begin{array}{c}\text { newcomer businessmen and } \\
\text { lobbyists }\end{array}$ & $\begin{array}{c}\text { forming a collaborator economy and } \\
\text { alternative institutions }\end{array}$ \\
\hline lowest & theory & neoliberals-theoretician & orchestrated apologetics and rhetorics \\
\hline
\end{tabular}

Source: Author's creation.

Therefore, they are basing their critical argument precisely on that erroneous premise. They orchestratedly talk and write about market freedom, competition, entrepreneurship, democracy, liberalism, development and pluralism, while in practice there are monopolies, inequality, poverty, exploitation, privilege and totalitarian order. Generally, these neoliberals accuse their anti-liberal critics (who advocate for institutional pluralism) to make „bad decisions." In this way, it seems that institutional pluralism is a bad decision!

\section{Liberalism vs. neoliberalism}

Identification of liberalism and neoliberalism in economic literature is very symptomatic. It is employed by the representatives of neoliberalism, to prove that it „does not exist“ (Mijatovic), and therefore that is an „unnecessary term“ (Prokopijević). Thus, for example. Lj. Madzar (2015, p. 146) points out: „Wise liberal-minded authors have long ago understood and repeatedly emphasized that prefix neo before the word liberalism is not necessary ... That's why they have added (anti-liberals - V.D.'s note) prefix neo ... which modern liberal-oriented scientists rejected, and with a good dose of indignation". The same author (Ibid.) writes: „The prefix neo is invented ... modern liberalism differs from classical liberalism in essential characteristics" (Ibid., p. 242).

However, in another place in the same work he (Ibid., p. 150) contradictory states that "liberalism is the normative form of social harmony within the law and the rule of law". Though, in this way he actually reveals the difference between liberalism and neoliberalism as the official economic policy of some countries in transition, which in practice is characterized by the opposite (quasi-neoliberal) manifestations and phenomena.

Liberalism is seen as a spectrum of human freedom (from political to economic). But it is obvious that word freedom has become a frequently used as a rhetorical symbol. T. C. Boas \& J. Gans-Morse (2009, p. 139) correctly state: „The term of neoliberalism first emerged in the studies of the Freiberg School of German economists to establish a doctrine that was explicitly moderate comparing to classical liberalism, by rejecting laissez-faire values and its emphasings on humanistic values". Their research shows that the term neoliberalism is rarely mentioned in the 1980s, but in the period 2002-2005 have been published nearly within 1,000 scientific articles per year. However, they consider (Ibid., p. 138) that in interpretating neoliberalism predominant concept of scholarly writing on development and political economy is outpacing related terms such as monetarism, neoconservatism, the Washington Consensus, and even market reform.

It is no coincidence that modern neoliberals advocate a ,minimal state“. For them it is the strongest link with classical liberalism. Modern liberalism is, on the other hand, characterised by a greater willingness to let the state become an active participant in the economy. Madžar alone (2005, p. 21) wrote that ,there are a lot more abundant potential 
flows of violence and coercion, which spontaneously arise from decentralized sources in the familiar Hobbesian environment".

At 2003 he correctly preferred the priority of economic institutions in relation to economic freedom: „all arguments in favor of liberalization imply the existence ... of a stable legal order and orderly institutional environment“ and stated (2003, pp. 37-42) that „even the most developed are not as liberal as it appears at first sight." Obviously, the reasons why he changed his mind are now in force, therefore he has accused the alleged anti-liberals (economists, university professors) for glorification of neoliberalism. It seems that this is a classic critique for criticism and propaganda of neoliberalism.

It is important that liberalism, as a general philosophical, political and ideological heritage (set of beliefs), is a very complex, multi-dimensional and quite debatable concept, more associated with political agendas, establishment of democracy and individual freedom. Neoliberalism primarily relates to a particular type of economic policy. Therefore, it should not be confused. According to A. Saad-Filho and D. Johnston (2005, p. 1), ,we live in neoliberal era". They identify it with the new paradigm and ideology of power and wealth, which are in the hands of transnational corporations and elites that shape contemporary world. T. Palley (2005), who argues that a ,great reversal“" has taken place, where neoliberalism has replaced the economic theories of J. M. Keynes and his followers.

The views on relation liberalism-neoliberalism and identification of liberalism and neoliberalism deserves a detailed explanation. Liberalism has evolved from the great scientific and intellectual doctrine, becoming a specific, ideological and apologetic economic policy, implemented for the interests of narrow and privileged social groups (ie. the „new elite"). Losing touch with its scientific and ethical grounds, ideology has always refered to them, proclaiming their alleged continuity.

Modern neoliberals are doing the same thing: they refer to the tradition of the great liberal thinkers of the past, ignoring the fact that they gained fame in the fight against feudal tyranny and absolutism, human rights, the constitution, and civil liberties. Regardless of identification and self-recognition, a little of classical liberalism has remained in neoliberalism. Furthermore, the frequent crises in developed countries have encouraged corporate and political elite to revive economic liberalism, which has been significantly initiated by the globalization.

There were many new forms, processes and manifestations. All this have given it the prefix „neo“. So neoliberalism emerged as a synonym for extreme deregulated economy, which is in many ways the opposite to the classical liberalism, collectivism and authoritarianism.

Neoliberalism of many transition countries figures as a official macroeconomic policy. Neoliberalism is a set of economic policies that have been widely used during the last 30 years or so. The main points of neoliberalism include:

- the rule of the market, no matter how much social damage this causes. Greater openness to international trade and investment, reduce wages. Price controls are out of question. All in all, a total freedom of movement for capital, goods and services,

- cutting public expenditure for social services like education and health care. reducing the safety-net for the poor,

- deregulation,

- privatization, and

- eliminating the concept of „the public good“ or „,community“ and replacing it with ,individual responsibility“. Indubitably, neoliberalism was and remains the subject of numerous scientific articles, studies, books and scientific monographs. Classical liberalism has its rightful place in textbooks of historical economic thought. 
Liberalization is not the same as the neoliberal and quasi-neoliberal violence against it (see more about violence at North, Wallis, and Weingast, 2009). Neoliberalism did not prevent societal violence. On the contrary, it helped its expansion in the countries with a policy of „limited access“, where some organizations and groups of elites were pulling the rent due to their privileges and some tacitly „special rights“. Those ,rights“ are created in an institutional vacuum environments, characterized by personal relations and ,strings“. Hence, the order is hectic and volatile, the politics is interwoven and it dominates the economy, a minority (elite) manages the masses, informal and alternative institutions (which are extremely personificated) prevail, and organizational structures are unstable.

Scientific and ideological and practical phenomenon of the post-socialist economic „neoliberalism“ (quasi-institutional monism) is not accidental. It has its clear sources, origins and motives. It has appeared at the time of the socialist collapse, as a response to long-term rule of vulgarized and dogmatized Marxist political economy. Encouraged by interest-motives in practice, and in the absence of the original development concept, ,reformers“ have chosen new vulgarization and improvisation, this time the Western neoliberalism, which protected the interests of large transnational capital, where the state borders have been developmental barriers.

Unsuccessful post-socialist modifications were created on other people's formulas and were functionally incorporated to support the philosophy of a big business in the global and local relations. In this way, the open (socialist) totalitarian dirigisme turned into a hidden totalitarian neoliberalism. It has directly created and produced a continued institutional improvisation and imitation, while strengthening opportunistic behavior and alternative institutions as quasi-substitutes of the formal and informal institutions (Marinescu, 2013; Iacobuta \& Pohoata, 2015). Due to the introduction of neoliberalism in some transition countries, including this implementation under the auspices of the state and the fact that nomenclature authorities have „grabbed“ the most - we can freely speak of a neoliberal dirigisme as a new form of dirigisme!

Neoliberal doctrine is based on an assumption that the distribution of social and collective action will be further developed by reforms, and market reform should create benefits to the whole society and that it represents a long-term public good. It is obvious that the mass is replaced by privileged individualists. In reality, neoliberalism has separated from its scientific and philosophical heritage, becoming a reactionary tool of elite (class of nonmarket enriched individuals, who have appropriated the results of many generations) and the ideology of limitless power of big capital and business, which has destroyed the middle class, allowing freedom of exploitation. In this sense, Z. Baletic (2005) points out: „The ideological dogmatism has become the 'standard' form of economic thought... a project of radical reorganization of the society in favor of one part of the social forces towards their special interests, visions and values".

All neoliberals (politicians, economists and others in the government and close to it) say they are democratic, freedom-loving, tolerant, development-oriented, pluralistic in everything, not just in one - they absolutize alleged „neoliberalism“ but they do not see its alternative (thus negating choice as the essence of democracy and economy, but also pluralistic institutional conditions in which that choice is to be fully exercised). Propaganda of „absolute truth“ is always a prelude to apologetics.

Messianism of economic neoliberalism as an incarnations of infinite market power and the ,ideal“" way of organizing the economy, is actually institutional and monistic myth. It is based on a system of discriminatory and double standards: rhetorically shaped fruitless imagination and practical implementation of narrow individualy motivated interests. The matrix that connects the ideological indoctrination, interest orientation and reactive rhetoric, still reproduces in the time of crisis and quasi-institutional space. 
Neoliberalism as a philosophy of methodological individualism has proven to be very suitable for building specific and dogmatic theoretical platform. It has served as a motto for fast and non-market acquisition of wealth, power, and economic freedom of the privileged, whom alibi-economists often equated with ,effective owners". Since the process of enrichment was not innovative, or productive, or inheritance, or of market character, it was a reflection of the extremely rapacious accumulation (with no risk). Therefore, it is clear that minorities got what population and/or state lost.

Quasi-neoliberals have maximally relativized the contrast and paradox (apparent, imposed) between individual and institutional. Paradox of this combination individual vs. institutional is just an illusion and delusion of quasi-neoliberals, because in reality their nonexclusivity is actual generator of that combination (Madžar, 2005, p. 27). Udoubtedly, individual and collective are inseparable components of the most institutional arrangements and overall institutional order in modern developed economies.

In their propaganda and practice, neoliberals have ignored the class relations, social differentiation and individualism in a mass scale. They have reduced the institution of state regulation to minimum services to the population (defense, justice and legislative system) and support of the market-based system, especially in the period of crisis and market fiasco (failure). Monistic quasi-market reforms in post-socialist transition period have failed to substitute the huge institutional vacuum, moreover, they have led to their expansion and transformation into a quasi-institutionalization.

\begin{tabular}{|c|c|c|}
\hline \multicolumn{3}{|c|}{ A L T E R N A T I V E I N S T I T U T I O N S } \\
\hline \multicolumn{3}{|c|}{ d o m i n a t i o n } \\
$\downarrow$ & $\Leftrightarrow$ & informal institutions \\
\hline formal institutions & $\Leftrightarrow$
\end{tabular}

Figure 2. The substance of neoliberal quasi-institutionalization

Source: Author's creation.

Quasi-institutionalization is possible only in politically desirable and strictly controlled institutional and economic conditions, which naturally bring to life exclusivity and contradiction (alternation) of institutional relations, which prevent real institutional change and institutional competition. In such quasi-institutional terms, in which sophisticated imposes and dominates sociopathological form of domination of alternative institutions (Figure 3), comes to production and reproduction of unlimited anti-institutional privileges of the few individuals who come from circles of nomenclature authorities and their lobbyists. Furthermore, there is an enormous and non-market enrichment of narrow groups of society based on privilege.

\section{Conclusions}

Maximising profits at any cost, regardless of its origin (mainly enrichment through transfering the state property into private) was and still is the most important value criteria of neoliberal economic formulas. This has not brought economic prosperity in the SEE countries, except for the rare and privileged individuals. It is a proven and visible result of vulgarisation of neoliberal thought and quasi-neoliberal absolutism of market freedom and exclusivity of its supporters, who were often formal or ideological „reformers" in the transitional countries of Southeast Europe. These countries today are drowning in social, 
economic and institutional problems, crisis, debt, poverty, inequality and rich sociopathological milieu.

The term neoliberalism contains a certain degree of vagueness and complexity. Regardless, it generates many negative social, political and economic phenomena, which clearly suggest a departure from the classical liberal tradition. A large number of authors utilize the concept of neoliberalism from a pejorative perspective. We do not approve them by ascertaining the difference between neoliberal model and quasi-neoliberal practice. The time of ideological consensus about neoliberal package has passed. The rhetorics of neoliberalism seems anachronistic and apologetic.

\section{References}

Agassi, J. (1960), Methodological Individualism, In: O’Neil, J. (ed.), Modes of Individualism and Collectivism, London: Heinemann.

Baletić, Z. (2005), Ekonomski liberalizam i ekonomska znanost, Radovi HAZU, 43, pp. 1-45.

Begović, B. (2015), Ekonomska nejednakost kao barijera privrednom rastu: r>g?, Ekonomske ideje i praksa, No. 15, pp. 175-202.

Boas, T.C. \& Gans-Morse, J. (2009), Neoliberalism: From New Liberal Philosophy to AntiLiberal Slogan, Studies in Comparative International Development, No. 44, pp. $137-$ 161.

Davis, J. (2006), Heterodox economics, the fragmentation of the mainstream, and embedded individual analysis, In: R. Garnett and J. Harvey (eds.), Future Directions in Heterodox Economics, Ann Arbor: University of Michigan Press.

Dequech, D. (2007), Neoclassical, Mainstream, ortodox, and Heterodox Economics, Journal of Posto Keynesian Economics, Vol. 30, No. 2, pp. 279-302.

Draskovic, V. (2014), Neoliberal metaphor - as a quasi-economic paradigm in function of vulgarized institutional monism and an experiment of interest, Celje - Osijek Czestochowa - Kotor: SPH.

Drašković, V., Drašković, M. (2013), Kritika metodološkog individualizma, EconomicsEkonomija, Vol. 19, No. 4, pp. 273-296.

Frolov, D. (2008), Metodologiceskiy institucionalizm: novij vzgljad na evoluciyu ekonomiceskoy nauki, Voprosi ekonomiki, No. 11, pp. 90-101.

Iacobuta, A.-O., \& Pohoata, I. (2015), Analysis of the State Failure in Several PostCommunist Countries from the Perspective of Institutional Quality and path Dependence. Transformations in Business \& Economics, 14(2A), 313-328.

Hodgson, G. (2007), Institutions and Individuals: Interaction and Evolution, Organization Studies, Vol. 28, No. 1, pp. 95-116.

Lakic, S., Draskovic, M., (2015a), Implications of Institutional Dispositions of Neoliberalism, Montenegrin Journal of Economics, Vol. 11, No. 2, 113-124.

Lakic, S., Draskovic, M., (2015b), Methodological Individualism and Methodological Institutionalism for Interdisciplinary Research, Montenegrin Journal of Economics, Vol. 11, No. 1, 53-67.

Lawson, T. (2006), The nature of heterodox economics, Cambridge Journal of Economics, No. 30, pp. 483-505.

Madžar, Lj. (2003), Enigme liberalizacije, Prizma, oktobar, pp. 36-43.

Madžar, Lj. (2005), Institucionalne prepreke individualnih sloboda, Pojedinac i država, Beograd: Institut društvenih nauka - Centar za ekonomska istraživanja, pp. 21-52.

Madžar, Lj. (2015), Moj obračun s njima: pošast preteranog državnog intervencionizma, Ekonomske ideje i praksa, No. 15, pp. 11-56. 
Marinescu, C. (2013), Institutional Quality of the Business Environment: some European Practices in a Comparative Analysis. Amfiteatru Economic, 15(33), 270-287.

North, D. C. (1997), Some Fundamental Puzzles in Economic History/Development, In: W. B. Arthur, S. N. Durlauf, D.A. Lane (eds.), The Economy as an Evolving Complex System II, Addison-Wesley.

North, D. C., Walis, J. J., Weingast, B. R. (2009), Violence and Social Orders - A Conceptual Framework for Interpreting Recorded Human History, Cambridge: The Syndicate of the Pres of the Cambridge University.

Palley, T. I. (2005), From Keynesianism to Neoliberalism: Shifting Paradigms, In: A. SaadFilho, D. Johnston, Neoliberalism - A Critical Reader, London: Pluto Press, pp. 20-29.

Prokopijević, M. (20115), Liberalni i državni kapitalizam, Ekonomske ideje i praksa, No. 15, pp. 99-126.

Rubinstein, A. (2013), Teorija opekaemih blag v optike sravnitel'noj metodologii, Naučnij doklad, Moskva: Institut ekonomiki RAN.

Saad-Filho, A., Johnston, D. (2005), Introduction, In: A. Saad-Filho, D. Johnston, Neoliberalism - A Critical Reader, London: Pluto Press, pp. 1-6.

Udehn, L. (2002), The Changing Face of Methodological Individualism, Annual Review of Sociology, No. 28, pp. 479-507. 